\title{
Research on the Promotion of Tourism Attraction of Red Research Tourism Products in Shaanxi Province
}

\author{
Chen Xiaoyan \\ History, Culture and Tourism Department, Shaanxi Xueqian Normal University, Xi'an Shaanxi, \\ 710100 China
}

Keywords: Red tourism products, Research tourism, Tourism attraction

\begin{abstract}
In the context of the the great travel age, coupled with the requirements of quality education for the political and ideological qualities of young people, the study of tourism has evolved. Red tourism, which has outstanding educational functions, undoubtedly plays an irreplaceable role in expanding research products, cultivating the ideological and political qualities of young people, and inheriting red genes. The red research tourism products in Shaanxi province have high quantity and taste, but it's less attractive to the teen population. Therefore, how to improve the tourism attractiveness of Shaanxi red research tourism products, it's has a very important meaning to promote the development of tourism in Shaanxi Province and improve the comprehensive tourism competition.
\end{abstract}

\section{Introduction}

Research tourism is a combination of theory and practice. It not only inherits the traditional form of study, but also adds new content and methods, and becomes a new form of tourism. Research tourism is not only a form of innovative education and teaching, but also the implication of inquiry learning combined with study tour. Red tourism is one of the most vivid ways to carry out patriotism education, revolutionary traditional education and nationalist party history education. It can not only enhance the students' sense of social responsibility, but also enhance students' social practice ability. The combination of red tourism and study tourism will greatly promote the quality education level of primary and secondary school students.

\section{Definition of red research tourism products}

General Secretary Xi Jinping pointed out that "red tourism is a vivid classroom for the inheritance of red culture", "the development of red tourism must be in the right direction, the core is to carry out red education and inherit the red gene which make the cadres and masses to accept the red spirit baptism." The red research tourism product refers to the tourism products that can carry forward the red spirit education and promote the national spirit and the value of the times, and practice the core values of socialism. Red tourism can combine patriotism education with research tourism, and broaden the depth and breadth of tourism products, cultivate the ideological and 
political qualities of tourism objects, achieve the purpose of inheriting the red spirit. Red tourism has an irreplaceable important position.

\section{The current situation of developing red research tourism products in Shaanxi Province}

\subsection{Basic situation of red research tourism products in Shaanxi Province}

Shaanxi has rich red research and tourism resources. The Party Central Committee has been working in northern Shaanxi for 13 years. It has gone through a long period of time since the Agrarian Revolution, the War of Resistance against Japan, the War of Liberation and after a long time. Because of the longest time and the most complete historical period, the red research tourism resources in shaanxi are also the most comprehensive and extensive areas.With Yan 'an in northern Shaanxi as the leader, Xi'an as the provincial capital is the focus of development, and southern Shaanxi as an extension, a complete red research tourism route has been constructed. According to the survey, there are 2,051 revolutionary sites in Shaanxi Province, and there are 486 influential red cultural tourism resources, including 360 in Yan'an, 37 in Yulin, 30 in Xi'an, 9 in Xianyang, 5 in Baoji, 18 in Weinan, and 4 in Tongchuan. 12 in Hanzhong, 7 in Ankang, 4 in Shangluo. Among them, there are 19 national-level patriotic education bases and 30 provincial-level patriotic education bases. This article gives a partial list of the red research tourism resources in Shaanxi Province.For example:Yan'an Revolutionary Memorial Hall,Former site of Yangjialing,Eighth Route Army Xi'an Office Memorial Hall,Xi'an Incident Memorial Hall,Shaanxi-gansu border zhaojin revolutionary base site,The old site of Ma Lun Revolution in Xunyi County, etc.

\subsection{Advantages of developing red research tourism products in Shaanxi Province}

\subsubsection{Shaanxi province has superior red tourism resource endowment, large quantity and high grade}

Shaanxi has an irreplaceable influence on the whole Chinese history and revolutionary process, especially in the revolutionary holy land of Yan'an. The Party Central Committee has fought here for 13 years, Left behind many popular history of revolutionary struggle and Countless red scenic spots.It's Far-reaching influence and unparalleled historical status have made Shaanxi a treasure trove of national red cultural resources.

\subsubsection{Shaanxi provincial government's strong support for the development of red research tourism policies}

According to the 《Outline of Red Tourism Development Plan of Shaanxi Province》, under the background of the national red tourism boom, Shaanxi Province has continuously strengthened resource integration, gradually developed quality tourism products, and macro-distributed red research tourism, relying on its superior resources and unique status. In the direction, increase the investment of red research tourism, and continuously increase the investment scale and intensity of red tourism products and projects to promote the healthy, sustainable and rapid development of red tourism.

\subsubsection{The market demand of red research tourism is vigorous}

Red research tourism is a thematic tourism activity, and its development should follow the development law of the tourism market. Red research tourism takes the domestic youth student class as the market main body. As a major education province, Shaanxi has 93 colleges and 
universities, 15 adult higher education institutions, 750 high school education schools, 1,691 junior high schools, 5,507 primary schools, 56 special education schools, and 4,319 private schools. The large-scale students in school, combined with red tourism as an important carrier of patriotic education and a vivid classroom of inheriting red culture, the importance and popularity of universities and primary and secondary schools make the red research tourism have a strong demand for the source market.

\subsubsection{The tourism development foundation is good, and the supporting tourism service facilities are complete.}

As the birthplace of Chinese culture and national, Shaanxi is the spiritual treasure house of Chinese revolution, Chinese geography and Chinese civilization, the tourism resources in the region are characterized by diversity and uniqueness. After decades of development, Shaanxi tourism has gradually established a relatively complete infrastructure for "food, housing, travel and entertainment", which has also created favorable conditions for the development of red research tourism.

\subsection{Problems in the Development of Red Research Tourism Products in Shaanxi Province}

With the support and encouragement of national policies, red research tourism is developing rapidly at present. However, in the process of developing red research tourism in Shaanxi province, there are still the following problems, which affect the development of red research tourism.

\subsubsection{The main body of the red research tourism product market is complex and the standard system has not yet been formed.}

At present, there is no specific method and policy measures for the development of red research tourism. The red research market is still in a state of relative confusion and lack of effective supervision. Lack of a unified standard evaluation system, market entities are not clear, and market behavior is more chaotic. There is no effective integrated development between the various red tourist areas, and the local regional environment, customs, and tourism resources in various regions have not been effectively combined. The surrounding radiation effects have not yet been formed, which has impaired its tourism attractiveness and economic benefits to some extent.

3.3.2 Red research tourism products lack design, depth and breadth of development, single product categories and lack of experiential projects.

The core attractions of the red research tourism products are mostly some battlefields, old sites, and cultural relics left over from the Revolutionary. due to the hard environment, all remains relatively humble, less attractive content for tourists, there is a gap compared with other forms of tourism, in addition, red tourism mostly focuses on tourism products, lack of experience elements and In-depth participatory projects

\subsubsection{The development and design of the red research tourism products deviate from the needs of the target market, and the problems of safety and transportation are highlighted}

The original red research tourism products are mainly aimed at young party members and cadres. In the process of development, the products pay more attention to"party spirit"education and party history education; while some educational institutions and travel agencies and other intermediary institutions often attach more importance to travel than studies, or without learning, which insufficient for the education of patriotic education, revolutionary traditional education, and the core 
values of Chinese socialism. Moreover, in the era of revolutionary wars, in order to conceal the defensive nature and the strategic requirements of "urban encircling the city", most of the red research tourism resources are located in remote mountainous areas with inconvenient transportation, economic backwardness, inconvenient transportation, there are also safety, traffic and other problems when teenagers are traveling in red research tours.

\section{Discussion on strategies to enhance the attractiveness of red research tourism products in Shaanxi Province}

\subsection{Deeply dig the cultural connotation of red tourism resources}

The red culture can be said to be the core of the red tourism resources. The monotonous and passive way of visiting cultural relics and viewing the old sites has gradually failed to meet the needs of today's tourists. Therefore, in order to enhance the attractiveness of red tourism destinations, we should first capture the essence of red tourism, explore the cultural connotation of red tourism resources, enhance its cultural appeal, and innovate cultural expressions, so that visitors can experience shock and gain spiritual understanding.

\subsection{Integrate all kinds of tourism resources in red tourism destinations}

Comprehensively excavating and sorting out red tourism and cultural resources, both through the protection and development of tangible objects such as historical sites, sites, sites, former residences, and various books and periodicals, as well as oral history, red stories, and red movies. Organizing and recording intangibles such as songs. By accelerating the inheritance and innovation of the red culture, we will innovate and achieve the inheritance and development of the red culture. Through the red tourism consumption upgrade, the development of supply and demand for research and tourism will be promoted. Through the innovative development of the red culture, we will promote the rapid and coordinated development of the entire industry in the region. To achieve its dross, to retain its essence, to combine ecological green development with red development, to break down geographical restrictions, industry restrictions, internal and external barriers, and to create an open development space with ecological wealth and green welfare.

\subsection{Promote the connotation of red research tourism and enhance the development and protection of red culture}

Red tourism resources are an irreplaceable important carrier of patriotism education in China. How to strengthen the protection of red tourism effectively, mainly from the three aspects of protection, excavation and promotion. First of all, it should be protection. Tangible material cultural heritage such as cultural relics and ruins of the site are protected and repaired. Intangible intangible cultural heritage such as poetry, songs and dances, film and television songs, etc. should be collected and rescued. Second, it should be mining. Excavating the revolutionary stories of the old revolutionary population in the same year may also be the slogan of word of mouth. Again, it should be promotion. The related carriers of the red tourism are preserved. These vectors have both static red cultural relics and dynamic songs and dances, movies and the like. Finally, the red tourism heritage can not be achieved by the single protection of individuals or organizations. It should strengthen the participation of the public and form a comprehensive citizen protection education awareness of red cultural heritage. 


\subsection{Designing red research tourism products that meet different age groups to enhance their attractiveness}

The design of red research tourism products should be designed and developed according to different consumer target groups. These designers can be composed of experts from adolescents, education experts, travel planners, and red experts in various industries.Develop red research tourism products for different ages, such as wearing red military uniforms, learning red songs, red knowledge contests, rehearsing red stage dramas, etc., and integrating red theme stories into research and learning in the form of real-life performances, highlighting the spiritual connotation of red culture and Ethnic theme

\subsection{Innovate the form of experience projects, enhance the participation of red tourism, and "move" the red history}

With the arrival of the era of tourism experience, the expectation of red tourists for red tourism is no longer a single sightseeing and education, but a strong interest in products that reflect their own characteristics and meet the needs of modern tourists. Adopt the form of a variety of presentation makes the red revolution and revolutionary display "move" rise, enhance red studies the appeal of tourism products and expressive, can let the masses of tourists, through the revolutionary battlefield, revisit live revolution, know our revolutionary from studies in the tourism to the establishment of new China to pay a little, to raise their self-cultivation.

\subsection{Technology promotes development and joint promotion of new media}

Based on the scenic spot, the research-oriented activity-led red research tourism network platform that is integrated into the scenic spot but operates independently can be submitted to the third-party R\&D management. The scenic spot actively supports and cooperates, and through the platform sharing channels and control of operating costs, Standardize services, brand awareness, and achieve sustainable development. You can also use the new media, such as vibrato, volcano video, etc., to shoot some innovative small videos that young people can accept to promote the red research tourism products, so that more young people can understand and know the red color of Shaanxi. Research tourism products.

4.7 The support and promotion of the government is the most important factor in the development of red research tourism products.

The development of red research tourism products is inseparable from the support and promotion of the government's macro policies. In addition, the coordination and support of local education systems, tourism departments, transportation departments, medical insurance and other industries and departments is also a rapid study of red tourism products. Development is an indispensable factor. Each industry or department establishes a working organization or industry alliance that supports the mutual support of red research tourism products, and formulates corresponding institutional guarantees for all aspects of red research tourism products, from policy, medical, health, transportation, security and other aspects and links. It is the correct way for the rapid and steady development of red research tourism products.

\section{Acknowledgements}

1) 2017 Xi'an Social Science Fund Project:” Research on the Development of Cultural Tourism 
Resources in Silk Road Economic Belt of Xi'an,(No.17W81)

2) 2015 Shaanxi Social Science and Art Project:” A Study on the Application of Folk Music Resources in Shaanxi Province-A Case Study of Northern Shaanxi Folk Songs,(No.2015GH04085)

3) 2016 Shaanxi XueQian Normal University Project:” A Study on the Application of Folk Music Resources in Shaanxi Province - A Case Study of Northern Shaanxi Folk Songs, (No.2016YBKJ046)

\section{References}

[1] Dou Wenzhang. Make Red Tourism a Bright Color in Research Tourism [J]. China Tourism Daily, November 25, 2016, A02 Edition.

[2] Chen yindan. Research and development of Xi 'an red research tourism products [J]. Overview of tourism (the second half of this month).

[3] Shi Kehan. Influencing factors of urban tourism attraction in Henan Province [J]. Modernization of shopping malls, 2016, No. 24, 107-109.

[4] Xia Jinhua. Research on the Construction and Promotion Strategy of Red Tourism Destination Attraction Evaluation System__ Taking Jinggangshan as an Example [D]. Yangzhou University 2014. 